\title{
DISCIPLINA HISTÓRIA DO DESIGN
}

\author{
Débora Gigli Buonano- gbuonano@uol.com.br
}

Universidade São Judas Tadeu - Design

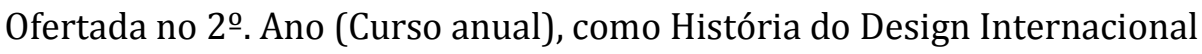

Curso Anual - Disciplina de 2 módulos

Carga horária total $=80$ horas

A História do design é discutida no curso como uma disciplina de reflexão, fundamentação e referência para o aluno na formação de conceitos que venha auxiliar no processo de construção e materialização do design.

\section{A DISCIPLINA ABORDA:}

a-contexto histórico

b-contexto sócio cultural e econômico, enfocando os designers e seus projetos

c-discute também as inovações tecnológicas

d-aborda também os teóricos do design

A disciplina debate inicialmente a Revolução Industrial, os britânicos com sua primeira escola de design em 1853, bem como destacamos o Museu Vitoria \& Albert como devotos especificamente em Artes Decorativas.

Na sequência o Palácio de Cristal em Londres e relacionamos o mesmo às teorias de Marx e Engels como uma exposição de poder, apresentamos também a crítica social de John Ruskim e deixamos claro o ataque materialista da Era Vitoriana, neste percurso focamos as práticas de William Morris, o Arts \& Crafts, a nova organização social e as novas condições da atividade econômica

Do mesmo modo, é focada a França como deslocamento cultural e artístico e de processo de modernização com o olhar crítico e analítico de Walter Benjamim. Celebramos o Art Nouveau e a importância dos Posters, a ornamentação da arquitetura e mobiliário, como inovações do século XX.

Buonano, Débora Gigli. "Disciplina História do Design”, in Anais do 10 Seminário Paulista do ensino da história do design 2014 [= Blucher Design Proceedings, num.3, vol. 1]. São Paulo: Blucher, 2014. 
Em um segundo momento evidênciamos as revoluções do século xx, as vanguardas, as novas regras da tipografia e novos conceitos do design gráfico moderno. No terceiro segmento, exibição, discussão e reflexão sobre a Bauhaus como produção e inovação no design gráfico, as fotomontagens, e sua influência pedagógica no ensino do Design, focando os teóricos da Escola. Em sentido contrário a esta visão apresentamos no mesmo módulo o Styling americano. Explanamos a modernidade como estilo triunfante do Art Deco francês e na sequência retornamos a discussão do conceito de funcionalismo sistematicamente desenvolvido na teoria e na prática da Escola de Design de ULM. No quarto módulo a disciplina pondera as questões do modernismo e explora o início da Pósmodernidade com teóricos como Jean Baudrillard, Adorno, Jean François Lyotard e Zigmund Bauman. No campo gráfico e abordado as revoluções e inovações, a escola Suíça de tipográfica, a escola americana, The Cranbrook Academy of Art, e o design gráfico conceitual e digital.

O encerramento da disciplina se dá com discussões como design sustentável, design thinking, bem como apresentamos designers e suas produções com os novos conceitos para o século XXI.

\section{CRITÉRIO DE AVALIAÇÃO}

Verificação da competência do aluno em apresentar o entendimento do conteúdo ministrado. A avaliação será realizada através de trabalhos de pesquisa, discussão de leituras e provas.

\section{BIBLIOGRAFIA BÁSICA}

DENIS, Rafael Cardoso. Uma introdução à história do design. São Paulo: Edgard Blücher Ltda, 2000.

SCHENEIDER, Beat. Design - Uma introdução: o design no contexto social, cultural e econômico. São Paulo, Editora Blücher, 2010.

SOUZA, Pedro L.P. dos. Notas para uma História do Design. Rio de Janeiro, 2AB, 1988. Qual o papel da história do design na formação que o curso oferece?

O Papel da História do Design é fundamental para reflexão dos projetos de design, porém, não consigo perceber o curso como um todo, e que essa ação realmente esta acontecendo.

Como os alunos percebem e avaliam a disciplina e seu impacto em suas formações? 
Alguns alunos percebem a importância da história, principalmente da história do design, e outros não compreendem que sem o conhecimento do passado é impossível projetar o futuro. 